\title{
Evaluasi Jumlah SelT-CD4 dan Berat Badan Anak dengan HIV/AIDS yang Mendapatkan Anti Retro Virus Lini Pertama di Rumah Sakit Dr. Saiful Anwar Malang
}

Irene Ratridewi

Divisi Infeksi dan Pediatri Tropis SMF/Lab Ilmu Kesehatan Anak Universitas Brawijaya/RSU Dr. Saiful Anwar, Malang

Latar belakang. Infeksi HIV merupakan masalah di dunia dan juga Indonesia. Peningkatan kejadian pada ibu hamil juga meningkatkan kasus HIV anak. Virus HIV menginfeksi dan menurunkan jumlah sel T CD4 sehingga menambah risiko terjadi infeksi oportunistik dan memperburuk gizi.

Tujuan. Mengevaluasi jumlah sel T CD4 dan berat badan pada pemberian anti retro virus (ARV) terhadap anak HIV/AIDS di RSU dr Saiful Anwar Malang.

Metode. Penelitian longitudinal mengukur CD4 dan perubahan berat badan pada anak HIV/AIDS dengan ARV lini pertama (zidovudine, lamivudine, nevirapine) lebih dari 6 bulan. Data disajikan dalam tabel dan gambar.

Hasil. Terdapat 13 kasus HIV (dari total 40) dengan ARV $\geq 6$ bulan, tanpa kasus meninggal. Rerata peningkatan berat badan setelah 6 bulan 29,6\% (12 kasus), 1 kasus berat badan turun 2,1\%, 6 bulan - 1 tahun $8,7 \%$ (11 kasus), 1 kasus berat badan turun $8 \%$. Rerata peningkatan berat badan dalam kurun, Waktu 1-1,5 tahun 7,9\% (pada 6 kasus), 1,5-2 tahun 6,5\% (3 kasus), 1 kasus berat badan turun 2\%, rerata peningkatan berat badan 2-2,5 tahun 11,5\% ( 2 kasus), dan 1 kasus telah mencapai 3 tahun pengobatan (berat badan meningkat 19,1\%). Jumlah sel T CD4 cenderung meningkat pada 11 kasus dan menurun pada 2 kasus.

Kesimpulan. Terdapat peningkatan jumlah sel T CD4 dan berat badan anak HIV/AIDS dengan ARV $\geq 6$ bulan. Obat ARV lini pertama masih dapat digunakan, perlu dipertimbangkan ARV lini kedua pada dua kasus yang mengalami kegagalan terapi. (Sari Pediatri 2009;11(4):276-81).

Kata kunci: HIV/AIDS, anak, CD4

\footnotetext{
Alamat korespondensi

Dr. Irene Ratridewi, SpA Divisi Infeksi dan Pediatri Tropis SMF/Lab Ilmu Kesehatan Anak Universitas Brawijaya/RSU dr Saiful Anwar Malang.
}

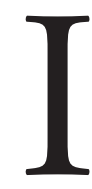

nfeksi HIV merupakan masalah dunia dan angka kejadiannya terus meningkat termasuk pada anak sejak dipublikasikan pertama kali pada tahun 1981. ${ }^{1,2}$ Saat ini perkembangan epidemi HIV di 
Indonesia termasuk yang tercepat di Asia dan berubah dari epidemi rendah menjadi epidemi terkonsentrasi. Data dari Depkes menyebutkan terdapat 32 provinsi dari 33 provinsi di Indonesia yang melaporkan kejadian HIV di wilayahnya berasal dari keseluruhan 178 kota/kabupaten. Peningkatan jumlah orang dewasa khususnya ibu hamil dengan HIV/AIDS akan meningkatkan risiko jumlah kasus bayi/anak dengan HIV/AIDS akibat penularan vertikal. Diperkirakan pada akhir 2015 akan terjadi penularan kumulatif pada lebih dari 38.500 anak yang dilahirkan dari ibu dengan HIV/AIDS. Di Jawa Timur terdapat 5260 kasus tercatat sampai dengan September 2009 dengan 147 kasus usia $<14$ tahun (118 terindikasi mendapat ARV, 93 orang masih mendapatkan ARV). ${ }^{3}$

Virus HIV masuk ke dalam tubuh manusia melalui kontak dengan cairan tubuh terinfeksi virus, dapat melalui parenteral (transfusi darah atau alat medis/ jarum terkontaminasi), transplasental, air susu ibu, dan hubungan seksual. Virus selanjutnya berikatan dengan reseptor permukaan sel T CD4 dan bereplikasi di dalamnya untuk menghasilkan virus baru dan menginfeksi sel T CD4 lain. Akibatnya terjadi penurunan jumlah sel T CD4 sampai akhirnya mencapai titik sehingga sistem imunitas tubuh menurun bermakna, dan mudah terserang infeksi oportunistik dan kerentanan terhadap infeksi baru. Infeksi HIV dan oportunistik yang berlangsung lama dan berulang menyebabkan gangguan keseimbangan nutrisi dan penurunan berat badan progresif. Semakin buruk nutrisi semakin rendah berat badan maka keadaan defisiensi imun semakin buruk, demikian seterusnya sampai terjadi perburukan kondisi umum berakhir dengan kematian.

Angka kematian akibat HIV/AIDS tinggi terutama pada anak sebelum era HAART (highly active anti retroviral therapy). Sejak pemakaian antiretroviral penyebab tersering kematian pada kasus HIV adalah infeksi oportunistik yang berat sangat berkurang. ${ }^{2}$ Banyak penelitian menyebutkan bahwa obat antiretroviral memberikan hasil yang sangat baik di berbagai negara. ${ }^{4,5,6}$ Berdasarkan rekomendasi WHO dan Departemen Kesehatan RI obat antiretroviral lini pertama yang direkomendasikan adalah 2 NRTI (2 jenis nucleoside reverse transcriptase inhibitor) dan 1 NNRTI (1 jenis non nucleoside reverse transcriptase inhibitor). Evaluasi terhadap efek pemberian ARV lini pertama telah dikerjakan di berbagai pusat perawatan dan penelitian HIV/AIDS tetapi belum pernah dikerjakan di RSU dr Saiful Anwar, Malang.

\section{Metode}

Penelitian longitudinal telah dilakukan untuk mengukur parameter klinis (berat badan) dan laboratoris (jumlah sel T CD4) pada anak dengan HIV/AIDS yang mendapatkan ARV selama $\geq 6$ bulan. Penelitian dikerjakan di unit rawat inap dan rawat jalan SMF/Lab Ilmu Kesehatan Anak RSU dr Saiful Anwar, Malang sejak Januari 2006 sampai dengan Juni 2009. Populasi subjek penelitian adalah seluruh pasien anak dengan HIV/AIDS yang berobat di unit rawat inap dan rawat jalan SMF/Lab Ilmu Kesehatan Anak RSU dr Saiful Anwar, Malang.

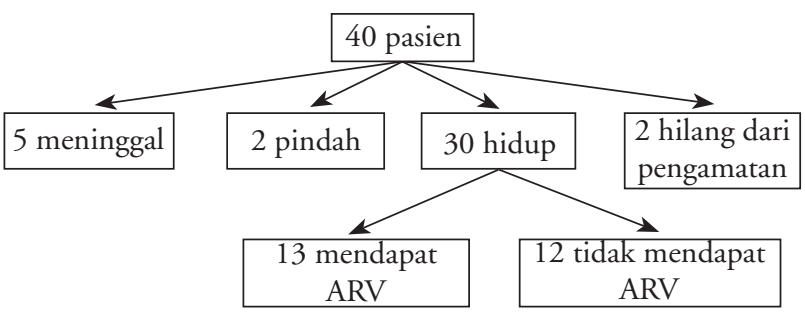

Gambar 1. Diagram pemilahan populasi penelitian

Tabel 1. Karakteristik pasien anak HIV/AIDS $(\mathrm{n}=40)$

\begin{tabular}{lc}
\hline Jumlah pasien & Frekuensi \\
\hline Seluruh pasien & 40 \\
Pasien yang meninggal (tanpa ARV, std 4) & 6 \\
Pasien pindah (ARV 2 bln, pindah VCT baru) & 2 \\
Kasus hilang dari pengamatan (ARV 1 bln) & 2 \\
Pengobatan ARV & \\
Lebih dari 6 bulan & 13 \\
Laki-laki lebih dari 6 bulan & 8 \\
Perempuan lebih dari 6 bulan & 5 \\
Status ibu & \\
HIV positif & 12 \\
Tidak diketahui & 1 \\
Status ayah & \\
HIV positif & 7 \\
HIV negatif & 2 \\
Tidak diketahui & 4 \\
Faktor risiko orangtua & \\
Riwayat IDU & 12 \\
Tidak diketahui & 1 \\
Infeksi oportunistik & \\
Diare melanjut & 9 \\
Moniliasis & 7 \\
TB paru & 12 \\
TB paru + TB kelenjar & 2 \\
Pneumonia & 6 \\
\hline
\end{tabular}


Infeksi oportunistik adalah semua penyakit infeksi (termasuk infeksi bakterial berulang) sesuai daftar keadaan yang mungkin terjadi pada AIDS. Bakteri atau parasit penyebab infeksi oportunistik tidak meluas dan fatal bila terjadi pada orang dengan status imunologi yang baik. Sel T CD4 adalah sel target dari HIV, sehingga jumlah atau persentase sel T CD4 sangat penting untuk menilai defisiensi imunologis dan keberhasilan pengobatan. Data CD4 untuk usia $<5$ tahun dinyatakan dalam persentase dan untuk usia $>5$ tahun dinyatakan dalam hitung absolut.

Obat ARV digunakan untuk menghambat retrovirus (terutama HIV). Jenis ARV digolongkan berdasarkan titik tangkap kerjanya terhadap retrovirus. Kelompok ARV lini pertama berdasarkan rekomendasi WHO dan Departemen Kesehatan RI adalah 2 NRTI dan 1 NNRTI. Obat yang digunakan di RSU Saiful Anwar adalah zidovudine + lamivudine dari golongan NRTI dan nevirapine dari golongan NNRTI.

Analisis kasus dilakukan terhadap pasien yang mendapatkan ARV $\geq 6$ bulan, data disajikan dalam bentuk tabel dan grafik.

\section{Hasil}

Sejak tahun 2006 telah dirawat 40 kasus HIV/AIDS pada anak di RSU dr Saiful Anwar Malang: 6 orang meninggal, 2 orang pindah rumah sakit, 2 orang lepas dari pengamatan, dan 30 orang hidup. Tigabelas orang telah mendapatkan ARV lini pertama selama 6 bulan atau lebih. Rerata usia pasien 50 bulan ( 4 tahun 2 bulan) dengan rentang 8-114 bulan. Beberapa kasus mempunyai data CD4 tidak lengkap karena keterbatasan biaya. Pemeriksaan viral load tidak dikerjakan pada semua pasien.

Rerata peningkatan berat badan setelah 6 bulan pengobatan pada 12 kasus 29,6\%, terdapat 1 kasus berat badan turun $2,1 \%$. Rerata peningkatan berat badan dalam kurun 6 bulan -1 tahun pengobatan $8,7 \%$ (11 kasus), 1 kasus mengalami penurunan berat badan 8\%, dan 1 kasus belum mencapai 1 tahun pengobatan. Rerata peningkatan berat badan dalam kurun 1-1,5 tahun pengobatan $7,9 \%$ (6 kasus).

Peningkatan berat badan dalam kurun 1,5-2 tahun pengobatan $6,5 \%$ (3 kasus), 1 kasus mengalami penurunan berat badan $2 \%$. Rerata peningkatan berat badan dalam kurun 2-2,5 tahun pengobatan 11,5\% (2 kasus), dan 1 kasus telah mencapai 3 tahun pengobatan dengan peningkatan berat badan dari 2,5 tahun 19,1\%. Dari data CD 4 terdapat 11 kasus dengan CD4 yang meningkat atau stabil, dan 2 kasus dengan penurunan CD4 (disertai dengan penurunan berat badan). Data CD4 terbanyak diperoleh setelah pengobatan 1 tahun. Rerata persentase peningkatan CD4 tidak dapat kami hitung karena data yang diperoleh memiliki satuan yang tidak seragam.

Tabel 2. Perubahan berat badan (kilogram) anak HIV/AIDS yang telah mendapat pengobatan ARV

\begin{tabular}{lccccccc}
\hline \multirow{2}{*}{ Umur } & \multicolumn{7}{c}{ Lama pengobatan ARV } \\
\cline { 2 - 7 } & I & II & III & IV & V & VI & VII \\
\hline 7 thn & 16,7 & 20 & 21,8 & & & & \\
6 thn & 11 & 14,9 & 16,5 & & & & \\
1 thn & 5,1 & 7,9 & 8,3 & & & & \\
2 thn 10 bl & 10 & 16,9 & 15,6 & & & & \\
2 thn 8 bl & 9,5 & 11 & 12,5 & 14,5 & & & \\
2 thn 6 bl & 9,6 & 9,4 & 10,5 & 12,5 & & & \\
7 thn & 16,5 & 17,3 & 18,5 & 19,2 & 20,5 & & \\
4 thn & 13,5 & 16 & 17,5 & & & & \\
2 thn 6 bln & 11 & 12,7 & 14,5 & 14,8 & 14,5 & 17,2 & 20,5 \\
4 thn & 20,5 & 24,5 & 25 & 25,5 & 27 & & \\
4 thn & 12 & 19 & 20,5 & 21,5 & 23 & 24 & \\
8 bl & 8 & 9,5 & 10 & & & & \\
1 thn 4 bl & 6,3 & 7,4 & & & & & \\
\hline
\end{tabular}

*I: berat badan sebelum ARV

II, III, IV, V, VI, VII, dan berturut-turut setelah ARV 6 bulan, 1, 1.5, 2, 2.5, dan 3 tahun 
Irene Ratridewi: Evaluasi jumlah sel T-CD4 dan berat badan anak dengan HIV/AIDS yang mendapatkan ARV lini pertama

Tabel 3. Perubahan jumlah sel T CD4 anak HIV/AIDS yang telah mendapat pengobatan ARV

\begin{tabular}{|c|c|c|c|c|c|c|c|c|}
\hline \multirow[t]{2}{*}{ Umur } & \multicolumn{7}{|c|}{ Lama pengobatan $\mathrm{ARV}^{*} \mathrm{n}(\%)$} & \multirow[t]{2}{*}{ Stadium } \\
\hline & I & II & III & IV & $\mathrm{V}$ & VI & VII & \\
\hline 7 thn & - & & 288 & & & & & 4 \\
\hline 6 thn & 25 & & 236 & & & & & 4 \\
\hline 1 thn & 6 & & 16 & & & & & 4 \\
\hline 2 thn $10 \mathrm{bl}$ & $25(1)$ & $1047 / 16$ & $403(10)$ & & & & & 4 \\
\hline 2 thn 8 bl & 1451 & & $974(23)$ & & & & & 3 \\
\hline 2 thn $6 \mathrm{bl}$ & - & & $2145(37)$ & $3107(31)$ & & & & 3 \\
\hline 7 thn & - & & 1337 & 1063 & 1191 & & & 3 \\
\hline 4 thn & $678(24)$ & & 840 & & & & & 3 \\
\hline 2 thn 6 bln & 152 & $92(2)$ & - & 234 & 152 & 152 & 92 & 2 \\
\hline 4 thn & $399(8)$ & & $500(14)$ & 544 & 419 & & & 3 \\
\hline 4 thn & $164(14)$ & $624(29)$ & - & 788 & 617 & 535 & & 4 \\
\hline $8 \mathrm{bl}$ & $457(13)$ & - & $108(5)$ & $477(13)$ & & & & 4 \\
\hline 1 thn $4 \mathrm{bl}$ & $1256(16)$ & & & & & & & 4 \\
\hline
\end{tabular}

*I: CD4 sebelum ARV

II, III, IV, V, VI, VII, dan berturut-turut setelah ARV 6 bulan, 1, 1.5, 2, 2.5, dan 3 tahun

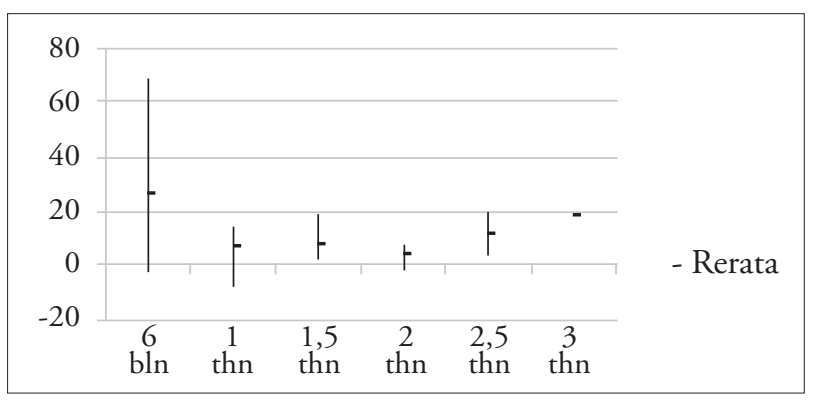

Gambar 2. Perubahan berat badan anak HIV/AIDS dengan ARV

\section{Diskusi}

Era HAART (highly active anti retroviral therapy) telah menyebabkan pasien HIV/AIDS dapat hidup lebih lama. Beberapa penelitian seperti Cowburn $\mathrm{dkk}^{7}$ menunjukkan HAART menurunkan mortalitas pada pasien HIV yang dirawat di ruang perawatan intensif. Kumarasamy $\mathrm{dkk}^{8}$ menyimpulkan dalam penelitiannya bahwa HAART generik lini pertama masih efektif, aman, dan dapat ditoleransi dengan baik oleh pasien HIV anak. Dalam studi kami semua pasien mendapatkan rejimen lini pertama berupa zidovudine, lamivudine, dan nevirapine. Stavudine tidak dipakai karena efek lipoatrofi dan toksisitas mitokondria yang lebih berat. ${ }^{9}$ Seluruh subjek pengamatan kami diperoleh dari rujukan VCT dan dugaan presumtif pasien yang dirawat. Semua pasien diduga tertular HIV secara vertikal tanpa program PMTCT (prevention mother to child transmission), ibu hamil yang menderita HIV seharusnya mendapatkan ARV prenatal dan bayi yang dilahirkan mendapatkan profilaksis ARV. ${ }^{10,11}$ Data pada pasien kami menunjukkan sebagian besar ibu pasien menderita HIV positif. Semua kasus yang meninggal tidak pernah mendapat ARV. Hal ini sesuai dengan penelitian dari Violari $\mathrm{dkk}^{12}$ yang menyatakan bahwa saat pemberian ARV yang tepat pada ibu hamil dan bayi terinfeksi HIV mengurangi morbiditas dan mortalitas bayi.

Penanganan kasus HIV/AIDS pada anak khususnya dengan gizi kurang atau gizi buruk melibatkan intervensi nutrisi. Intervensi nutrisi yang baik selain upaya pemenuhan karbohidrat, protein, lemak, juga meliputi vitamin, mineral, dan nutrisi mikro. Perbaikan asupan nutrisi mikro berpengaruh terhadap keberhasilan ARV. ${ }^{13}$ Intervensi dan pemantauan nutrisi kami kerjakan pada semua kasus. Penanganan kasus HIV/AIDS pada anak khususnya dengan gizi kurang atau gizi buruk melibatkan intervensi nutrisi.

Secara umum rerata peningkatan berat badan pada 6 bulan pengobatan $(29,6 \%)$ dibandingkan dengan 6 bulan berikutnya (sesudah 1 tahun pengobatan, 8,7\%). Jumlah sel T CD4 sering dihubungkan dengan kejadian dan keparahan infeksi oportunistik, tetapi pada data kami terdapat kasus usia $<5$ tahun dengan CD $4<15 \%$ dengan stadium klinis 2 atau 3, artinya 
secara imunologis terdapat imunosupresi berat tetapi secara klinis belum mencapai stadium 4 . Terdapat 2 kasus (kasus 4 dan 9) mengalami peningkatan CD4 dan berat badan setelah pengobatan ARV selama 1 tahun tetapi kemudian terjadi penurunan CD4 dan berat badan. Pada kasus seperti ini kami lakukan pemeriksaan viral load, pengamatan lebih lanjut mengenai adherence (ketepatan dosis, ketepatan waktu minum obat, dan jenis obat yang diperoleh), dan klinis termasuk infeksi oportunistik baru/berulang.

Kegagalan pengobatan ditetapkan bila tidak terdapat perbaikan viral load, CD4, atau klinis. Penyebab kegagalan pengobatan adalah resistensi virus terhadap obat, ketidakpatuhan minum obat, dan atau interaksi obat. Resistensi virus terhadap obat dipastikan dengan uji genotip dan fenotip virus yang dapat menentukan letak mutasi DNA virus, sehingga pemilihan ARV berikutnya dapat lebih tepat. ${ }^{14,15,16}$ Mengingat pemeriksaan genetik virus belum memungkinkan untuk dikerjakan maka resistensi obat dipertimbangkan sebagai salah satu kemungkinan bila adherence, kepatuhan berobat, dosis, dan jadwal yang tepat telah dikerjakan. Adherence adalah kunci penting dalam keberhasilan ARV, penelitian di Nigeria juga menyampaikan buruknya adherence meningkatkan gagal pengobatan dan risiko resistensi. ${ }^{17}$ Beberapa hal yang mempengaruhi kepatuhan adalah jadwal minum obat (pengasuh sering lupa memberikan), anak menolak minum obat, dan efek samping mual/ muntah. Pada kasus 4 dan 9 seharusnya pemeriksaan viral load dikerjakan, tetapi parameter imunologi dan klinis (penurunan berat badan) menunjukkan kegagalan pengobatan sehingga boleh dipertimbangkan mengubah rejimen terapi menjadi lini kedua. ${ }^{18}$ Studi di Kamboja dengan jumlah subjek yang lebih besar menunjukkan hasil ARV lini pertama masih dapat dipakai setidaknya dalam 12 bulan pengobatan dengan peningkatan jumlah sel T CD4 75\%. ${ }^{4}$ Studi kami juga menunjukkan kecenderungan peningkatan jumlah sel T CD4 individual (mengingat tidak semua data CD4 diperiksa).

Committee on Pediatric AIDS dari AAP (American association of pediatrics) menyatakan terdapat beberapa kendala dalam pengelolaan HIV/AIDS anak yang perlu diperbaiki yaitu keterbatasan diagnosis terutama untuk PCR yang relatif mahal untuk negara berkembang/ miskin, sarana perawatan kurang memadai, pemenuhan kebutuhan nutrisi, masalah formulasi, dosis, serta ketersediaan obat ARV. ${ }^{19,20}$ Kendala yang diungkapkan oleh komite tersebut juga menjadi kendala kami seperti diagnosis (khususnya PCR) dan formulasi obat (jenis dan jumlah ARV tertentu terbatas terutama dalam bentuk FDC fixed drug combination). Saat ini Departemen Kesehatan RI sedang mengupayakan distribusi formulasi FDC dan mengembangkan sistem roda dosis (dosing wheel) untuk memudahkan penulisan/peresepan obat. Di rumah sakit Dr. Saiful Anwar, Malang formulasi FDC (dalam jumlah terbatas), dosing wheel, dan program bantuan nutrisi untuk pasien HIV/AIDS telah dikerjakan. Kami akan memperbaiki pencatatan dan pelaporan data pasien untuk penelitian lebih lanjut untuk mendapatkan hasil yang lebih akurat.

Kesimpulan dari pengamatan kami terdapat peningkatan berat badan setelah pengobatan dengan ARV lini pertama, terjadi peningkatan CD4 setelah pengobatan dengan ARV lini pertama, pengobatan ARV lini pertama masih dapat digunakan untuk anak dengan HIV/AIDS di RSU dr Saiful Anwar Malang, dan kegagalan terapi terjadi pada 2 kasus dan dipertimbangkan untuk mengubah ARV ke lini kedua.

\section{Ucapan terimakasih}

Ucapan terimakasih saya ucapkan kepada Prof. DR. dr. Sri Rezeki Hadinegoro, $\operatorname{SpA}(\mathrm{K})$, dr. Hindra Irawan Satari, $\operatorname{SpA}(\mathrm{K})$, dr. Alan R. Tumbelaka, $\operatorname{SpA}(\mathrm{K})$, dr. Ari Prayitno, SpA, dr. Mulya R. Karyanti, SpA, dr. Nia Kurniati, SpA(K), dr. Tonny Sunjaya, dr. Setya Budhy, $\operatorname{SpA}(\mathrm{K})$, dr. Sumakto, $\mathrm{SpA}(\mathrm{K})$, atas bimbingan dalam penulisan makalah ini. Kepada dr. Niken Susanti, dr. Dessy, peserta PPDS1 FKUB/RSSA Malang, terima kasih atas pengumpulan data pasien.

\section{Daftar Pustaka}

1. Neisheim SR, Kapogiannis BG, Soe MM, Sullivan KM, Abrams E, Farley J, dkk. Trends in Opportunistic Infections in the Pre- and Post-Highly Active Antiretroviral Therapy Eras Among HIV-Infected Children in the Perinatal AIDS Collaborative Transmission Study, 1986-2004. Pediatrics 2007; 120:100-9.

2. Bolton-Moore C, Mwangelwa Mubiana-Mbewe, Cantrell EA. Clinical outcomes and CD4 cell response in children receiving antiretroviral therapy at primary health 
Irene Ratridewi: Evaluasi jumlah sel T-CD4 dan berat badan anak dengan HIV/AIDS yang mendapatkan ARV lini pertama

care facilities in Zambia. JAMA 2007;298:1888-99.

3. Depkes RI. Pedoman tata laksana infeksi HIV dan pengobatan antiretroviral pada anak di Indonesia. 2008.

4. Jansenns B, Raleigh B, Soeung S, Akaob K, Te V, Gupta J, dkk. Effectiveness of highly active antiretroviral therapy in HIV-positive children: evaluation at 12 months in a routine program in Cambodia Pediatrics 2007;120:e1134-e1140.

5. Song R, Jelagat J, Dzombo D, Mwalimu M, Mandaliya K, Shikely K, Essajee S, dkk. Efficacy of highly active antiretroviral therapy in HIV-1-infected children in Kenya. Pediatrics 2007;120;e856-e61.

6. Larru B, Resino S, Bello JM, de Jose MI, Fortuny C, Navarro ML, dkk. Long-term response to highly active antiretroviral therapy with lopinavir/ritonavir in pretreated vertically HIV-infected children. J Antimicrob Chemother 2008;61:183-90.

7. Cowburn C, Hatherill M, Eley B, Nuttall J, Hussey G, Reynolds L, dkk. Short-term mortality and implementation of antiretroviral treatment for critically ill HIV-infected children in a developing country. Arch Dis Child 2007;92:234-41.

8. Kumarasamy N, Venkatesh KK, Devaleenol B, Poongulali, Mothi SN, Solomona S. Safety, tolerability and effectiveness of generic HAART in HIV-infected children in South India. J Trop Pediatr 2008;55:155-9.

9. Foster C, Lyall H. HIV and mitochondrial toxicity in children. J Antimicrob Chemother 2008; 61: 8-12.

10. Peter L. Havens, MD, Lynne M. Mofenson, MD, Committee on Pediatric AIDS. Evaluation and management of the infant exposed to HIV-1 in the United States. Pediatrics 2009;123:175-87.

11. Read JS, Committee on Pediatric AIDS. Diagnosis of HIV-1 infection in children younger than 18 months in the United States. Pediatrics 2007;120;e1547-e62.

12. Violari A, Cotton MF, Gibb DM, Babiker AG, Steyn J, Madhi SA, dkk. Early antiretroviral therapy and mortality among HIV-infected infants. N Engl J Med 2008;359:2233-44.
13. Drain PK, Kupka R, Mugusi F, and Fawzi WW. Micronutrients in HIV-positive persons receiving highly active antiretroviral therapy. Am J Clin Nutr 2007; 85: 333-45.

14. Winters MA, Merigan TC. Insertions in the human immunodeficiency virus type 1 protease and reverse transcriptase genes: clinical impact and molecular mechanisms. Antimicrob Agents Chemother 2005; 49:2575-82.

15. Barbour JD, Deeks SG. Clinical implications of HIV fitness and virulence. Dalam: Volberding PA, Sande MA, Lange J, Greene WC, penyunting. Global HIV/AIDS medicine. China: Saunders Elsevier; 2008.h.161-9.

16. Brindeiro PA, Brindeiro RM, Mortensen C, Hertogs K, De Vroey V, Rubini NPM, dkk. Testing genotypic and phenotypic resistance in human immunodeficiency virus type 1 isolates of clade $B$ and other clades from children failing antiretroviral therapy. J Clin Microbiol 2002;40:4512-9.

17. Uzochukwu BSC, Onwujekwe OE, Onoka AC, Okoli C, Uguru NP, Chukwuogo OI. Determinants of nonadherence to subsidized anti-retroviral treatment in southeast Nigeria. Health Policy and Planning 2009;24:189-96.

18. Kapogiannis BG, Soe MM, Nesheim SR, Sullivan KM, Abrams E, Farley J, dkk. Trends in bacteremia in the pre- and post-highly active antiretroviral therapy era among HIV-infected children in the US perinatal AIDS collaborative transmission study (1986-2004). Pediatrics 2008;121:e1229-39.

19. Committee on Pediatric AIDS. Section on international child health. increasing antiretroviral drug access for children with HIV infection. Pediatrics 2007; 119: 83845.

20. Ponnet M, Frederix K, Petdachai W, Wilson D, Eksaengsri A, Zacharia R. A drug dosage table is a useful tool to facilitate prescriptions of antiretroviral drugs for children in Thailand. Int J STD AIDS 2005;16:420-6. 